\title{
Is mean platelet volume a helpful parameter in diagnosing periprosthetic joint infection?
}

\section{Ortalama trombosit hacmi periprostetik eklem enfeksiyonunun tanısında faydalı bir parametre midir?}

\author{
Ahmet Onur Akpolat ${ }^{1 *}$ (D), Demet Pepele Kurdal ${ }^{1}$ (D), Mehmet Fatih Aksay ${ }^{1}$ \\ ${ }^{1}$ Fatih Sultan Mehmet Training and Research Hospital, Orthopaedics and Traumatology Clinic, 34856 Ataşehir/Istanbul, Turkey \\ * Corresponding author: Ahmet Onur Akpolat E-mail: onurakpolat@hotmail.com ORCID: 0000-0001-7773-5476 \\ Received: 21 April 2020 Accepted: 11 July 2020
}

\begin{abstract}
Introduction: Mean Platelet Volume (MPV) is encountered in the literature as a diagnostic marker used to monitor infectious and inflammatory events. We aimed to investigate whether or not there was a change in platelet and MPV parameters in patients diagnosed with periprosthetic join infection (PJI).
\end{abstract}

Material and Methods: A total of 110 patients were included in the study, consisting of $37(33.6 \%)$ patients with periprosthetic join infection, 38 (34.6\%) patients with total knee arthroplasty (TKA), and 35 (31.8\%) control group subjects. During the preoperative period and follow-up, MPV, platelet, erythrocyte sedimentation rate (ESR) and C-reactive protein $(C R P)$ values were assessed from routine laboratory tests. Statistical analyses of values between and within groups were conducted using Shapiro-Wilk test, One-way ANOVA, Bonferroni's test, Pearson's test, and Chi-square test. $\mathrm{P}<0.05$ and $\mathrm{p}<0.01$ values were considered statistically significant.

Results: There was no statistically significant difference among the groups according to preoperative platelet and MPV values ( $p>0.05$ ). Postoperative MPV levels were significantly lower and platelet, ESR and CRP levels were significantly high in the PJI group compared to both the control group and the TKA group $(p<0.05)$.

Conclusion: MPV is a useful laboratory parameter in the diagnosis of periprosthetic joint infection in patients.

Keywords: Mean Platelet Volume, periprostatic, infection, diagnosis, knee

() 2020 by the authors; licensee MEDITAGEM Ltd., Turkey. This article is an open access article distributed under the terms and conditions of the Creative Commons Attribution License (http://creativecommons.org/licenses/by/4.0/). 


\section{ÖZ}

Giriş: Literatürde Ortalama Trombosit hacminin (OTH) enfeksiyöz ve inflamatuar olaylarda bir tanı belirteci olarak kullanıldığı görülmektedir. Amacımız OTH'nin periprostetik eklem enfeksiyonu tanısında yararlı bir parametre olup olmadığını araştırmaktır.

Araç ve Yöntemler: Çalışmaya $37(\% 33,6)$ periprostetik eklem infeksiyonlu, $38(\% 34,6)$ diz artroplastili ve $35(\% 31,8)$ kontrol grubunu oluşturan 110 hasta dahil edildi. Preoperatif dönem ve kontroller sırasında alınan rutin laboratuvar örneklerinde OTH, trombosit, eritrosit sedimantasyon hızı (ESR) ve C reaktif protein (CRP) değerlerine bakıldı. Sonuçlar grup içi ve gruplar arasında Shapiro-Wilk, One-way ANOVA, Bonferroni, tPearson's, Chi-square testleri ile istatiksel olarak değerlendirildi. $p<0.05$ ve $p<0.01$ değerleri anlamlı kabul edildi.

Bulgular: Preoperatif dönemde grupların trombosit ve OTH değerleri arasında istatiksel fark saptanmadı. Periprostatik eklem enfeksiyonu olan grubun postoperatif OTH düzeyleri hem kontrol hem de TKA grubuna göre anlamlı düşük, trombosit, CRP ve ESR düzeyleri ise anlamlı yüksek saptandı $(p<0.05)$.

Sonuç: OTH periprostetik eklem enfeksiyonu tanısında kullanılabilecek faydalı bir laboratuvar parametresidir.

Anahtar kelimeler: Ortalama Trombosit Hacmi, periprostetik, enfeksiyon, tanı, diz

\section{INTRODUCTION}

Periprosthetic joint infection (PJI) is a complication encountered by nearly every orthopedics specialist. Its incidence rate after primary knee arthroplasty is between $0.4-2 \%$ while its incidence after revision knee arthroplasty surgery is $3.2-5 \%$ [1-3]. PJI of the knee remains a major challenge as there is no test with absolute accuracy $[4,5]$. The diagnosis of $\mathrm{PJI}$ is based on a combination of clinical findings, laboratory results from peripheral blood and synovial fluid, microbiological culture, histological evaluation of periprosthetic tissue, and intraoperative findings $[4,5]$.

Mean platelet volume (MPV) is assessed as a part of routine complete blood count (CBC) analysis. MPV is a parameter defined as an indicator of platelet activation and function [6]. Recently, there is increased interest in MPV as a diagnostic marker used in the follow-up of infectious events [7]. Studies reported that infectious events cause various responses in platelet and MPV levels $[7,8]$.

This study aims to evaluate whether or not MPV is a useful parameter in diagnosing periprosthetic knee infection.

\section{MATERIAL AND METHODS}

\section{Study Design}

This retrospective clinical study was performed with the approval of the Insitutional Review Board and in line with the ethical principles of the Declaration of Helsinki. After approval of the institutional review board, informed consent was obtained from the guardians of all participants.

\section{Setting}

Patients were identified from a single tertiary academic medical center.

\section{Participants}

Patients who were followed up at our institute between January 2013-October 2018 were included in the study. Inclusion criteria were; procedure of bilateral knee prosthesis, no presence of infection other than PJI, at least six months of regular follow-up, and no clinical history of inflammatory disease and/or surgical intervention which may affect MPV value. Exclusion criteria included presence of systemic disease (dyslipidemia, uncontrolled DM, hypertension, etc.), peripheral circulatory disorders, cerebrovascular diseases, inflammatory arthropathy, alcohol-smoking, liver and/or kidney failure, immunosuppressive drug use, and malignancy.

\section{Groups}

TKA Group: Patients who underwent total knee arthroplasty without clinical or laboratory signs of infection.

PJI Group: Patients who were diagnosed with PJl according to Musculoskeletal Infection Society (MSIS) criteria and had growth in intraoperatively collected tissue samples. 
Table 1. Demographic Evaluation of Groups

\begin{tabular}{|c|c|c|c|c|c|}
\hline & & $\begin{array}{c}\text { PJI } \\
n=37(\% 33.6)\end{array}$ & $\begin{array}{c}\text { TKA } \\
n=38(\% 34.6)\end{array}$ & $\begin{array}{c}\text { Control } \\
n=35(\% 31.8)\end{array}$ & $p$ \\
\hline \multirow{2}{*}{ Age (Year) } & Min-Max (Median) & $58-81$ (69) & $53-87(70.5)$ & $22-67(30)$ & \multirow{2}{*}{$0.001 * *$} \\
\hline & Mean $\pm S D$ & $68.27 \pm 5.33$ & $70.55 \pm 7.71$ & $39.54 \pm 15.32$ & \\
\hline \multirow{2}{*}{ Gender; n (\%) } & Woman & $28(75.6)$ & $28(73.6)$ & $18(51.4)$ & \multirow{2}{*}{0.082} \\
\hline & Man & $9(24.3)$ & $10(26.3)$ & $17(48.5)$ & \\
\hline
\end{tabular}

Control Group: Patients without any pathological condition detected during routine health examinations or laboratory results.

\section{Laboratory and Sample Collecting Methods}

Laboratory analyses of peripheral blood samples included platelet count, MPV, erythrocyte sedimentation rate (ESR) and C-reactive protein (CRP) values. Blood samples were collected during the preoperative planning period and sixmonth postoperative period in the TKA group, during the preoperative planning period before arthroplasty operation and also during the reoperation period after diagnosis of $\mathrm{PJI}$ in the PJI group, and during routine health screening in the control group. Inter-group and intra-group comparisons of the blood sample results were made and the data was statistically analyzed.

\section{Biomarkers Measurement}

Platelet count (reference range 4-10 x10 9/L), MPV (reference range 7.5 and 12.0) were analyzed with a hematological blood analyzer LH75 (Beckman Coulter). The serum concentration of CRP (reference range $0-0,5 \mathrm{mg} / \mathrm{L}$ ) was measured using the immunoturbidimetric method, and ESR (reference range $0-20 \mathrm{~mm} / \mathrm{h}$ ) was also measured using ESR auto analyzer (electra; Italy).

\section{Statistical Analysis}

The NCSS (Number Cruncher Statistical System) 2007 (Kaysville, Utah, USA) program was used for statistical analysis. Descriptive statistical methods (mean, standard deviation, median, frequency, percentage, minimum, maximum) were used when evaluating study data. The normal distribution of quantitative data was tested with Shapiro-Wilk test and graphical investigations. Student t test was used for the comparison of two groups with normal distribution. One-way ANOVA was used for comparison of three or more groups with normal distribution and Bonferroni test for multiple comparison. Paired Samples ttest was used for preoperative and postoperative evaluation of measurements within the group. Pearson's Chi-square test was used for comparison of qualitative data. Diagnostic screening tests (sensitivity, specificity, PPV, NPV) and ROC Curve analysis was used to determine cutoff values.
Correlation analysis was performed to assess the relationships between platelet count, MPV, ESR, and CRP values. The value of $p<0.05$ was considered statistically significant.

\section{RESULTS}

\section{Demographic Evaluation}

A total of 110 patients (74 [67.3\%] female, 36 [32.7\%] male) were included in the study. Mean patient age was $59.92 \pm 17.30$ (22-87) years. The PJI group consisted of 37 (33.6\%) patients, the TKA group consisted of 38 (34.6\%) patients, and the control group consisted of 35 (31.8\%) patients (Table 1).

In the PJI group, the mean amount of time from initial operation to PJI diagnosis was $11.86 \pm 4.2$ (7-26) months. Mean follow-up time of the TKA group was 13.12 \pm 2.8 (8-20) months.

Patients in the PJI and TKA groups were significantly older than patients in the control group $(p<0.01)$. There was no statistically significant difference between the PJI and TKA groups according to age ( $p>0.01)$. There was no significant difference between the groups according to gender distribution ( $p>0.05$ ) (Table 1).

In PJI tissue samples, coagulase-negative staphylococci growth was observed in 11 (29.72\%), Staphylococci aureus in $6(16.21 \%)$, anaerobic bacteria in $4(10.81 \%)$, gram negative bacilli in $3(8.1 \%)$, mixed flora in $3(8.1 \%)$, and Enterococcus spp. in 2 (5.4\%).

\section{Comparison between Groups}

There was no statistically significant difference between the initial samples of the groups according to platelet count, MPV, ESR, or CRP values ( $p>0.05$ ). There was, however, a significant difference between the second samples of the groups $(p<0.01)$. In order to determine the group causing this significant difference, results of two-way test showed that platelet count, MPV, ESR, and CRP values of the PJI group were significantly different compared to the other groups; while platelet count, ESR, and CRP values were significantly higher, MPV was significantly lower. According 
Akpolat et al. / Is MPV helpful in periprosthetic joint infection?

Table 2. Intra-group Evaluation and Comparison Between Groups

\begin{tabular}{|c|c|c|c|c|}
\hline & $\begin{array}{c}\text { PNI group }(\mathrm{n}=37) \\
\text { Mean } \pm S D(\text { Min-Max })\end{array}$ & $\begin{array}{c}\text { TKA }(\mathrm{n}=38) \\
\text { Mean } \pm S D(\text { Min-Max })\end{array}$ & $\begin{array}{c}\text { Control }(\mathrm{n}=35) \\
\text { Mean } \pm S D(\text { Min-Max })\end{array}$ & $\mathbf{p}$ \\
\hline \multicolumn{5}{|l|}{ Platelet Count } \\
\hline First sample & $385.30 \pm 75.09(315-412)$ & $383 \pm 63.22(322-403)$ & $380.92 \pm 58.17(325-388)$ & 0.23 \\
\hline Second sample & $411.30 \pm 102.28(326-455)$ & $382.13 \pm 71.26(311-401)$ & $380.92 \pm 58.17(325-388)$ & $0.001 * *$ \\
\hline $\mathbf{p}$ & $0.001 * *$ & 0.258 & & \\
\hline \multicolumn{5}{|l|}{ MPV } \\
\hline First sample & $7.91 \pm 3.18(6.1-10.7)$ & $8.09 \pm 2.89(6.5-10.8)$ & $8.03 \pm 2.11(6.3-10.1)$ & 0.52 \\
\hline Second sample & $7.32 \pm 4.48(5.1-8.2)$ & $7.98 \pm 4.89(5.5-9.8)$ & $8.03 \pm 2.11(6.3-10.1)$ & $0.001 * *$ \\
\hline $\mathbf{p}$ & $0.001 * *$ & 0.651 & & \\
\hline \multicolumn{5}{|l|}{ ESR } \\
\hline First sample & $7.98 \pm 4.01(5-18)$ & $8.19 \pm 4.45(2-19)$ & $8.89 \pm 4.33(2-15)$ & 0.76 \\
\hline Second sample & $54.98 \pm 23.77(16-85)$ & $8.97 \pm 12.45(4-45)$ & $8.89 \pm 4.33(6-23)$ & $0.001 * *$ \\
\hline $\mathbf{p}$ & $0.001 * *$ & 0.465 & & \\
\hline \multicolumn{5}{|l|}{ CRP } \\
\hline First sample & $0.15 \pm 0.21(0-0.4)$ & $0.22 \pm 0.11(0-0.4)$ & $0.13 \pm 0.18(0-0.3)$ & 0.83 \\
\hline Second sample & $4.56 \pm 3.32(1.8-9.7)$ & $0.35 \pm 0.16(0-0.3)$ & $0.13 \pm 0.18(0-0.3)$ & $0.001 * *$ \\
\hline $\mathbf{p}$ & $0.001 * *$ & 0.489 & & \\
\hline
\end{tabular}

Table 3. MPV cut-off value and ROC Curve Results in the PJI group

\begin{tabular}{|c|c|c|c|c|c|c|c|c|}
\hline & \multicolumn{5}{|c|}{ Diagnostic Scan } & \multicolumn{2}{|c|}{ ROC Curve } & \multirow[b]{2}{*}{$p$} \\
\hline & Cut off & Sensitivite & Spesifisite & $\begin{array}{c}\text { Positive } \\
\text { Predictive } \\
\text { Value }\end{array}$ & $\begin{array}{c}\text { Negative } \\
\text { Predictive } \\
\text { Value }\end{array}$ & Area & $\begin{array}{c}95 \% \\
\text { Confidence } \\
\text { Interval }\end{array}$ & \\
\hline MPV & $\leq 7.2$ & 47.37 & 85.71 & 78.26 & 60.00 & 0.650 & $0.525-0.776$ & $0.027^{*}$ \\
\hline
\end{tabular}

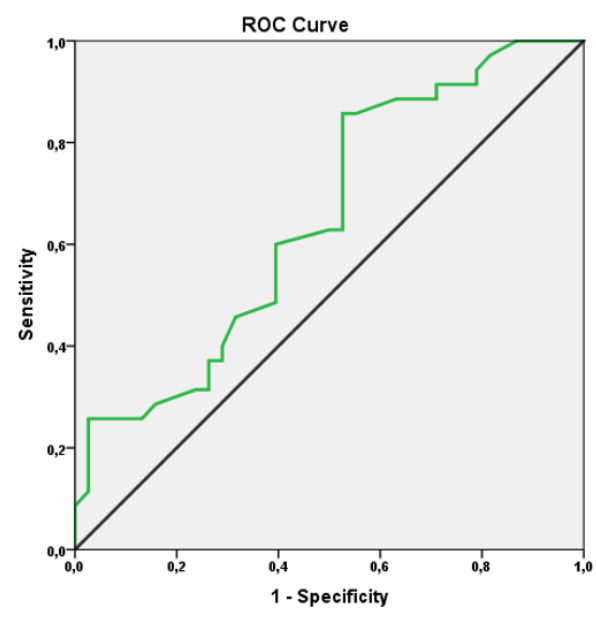

to the two-way test, there was no significant difference between the control group and the TKA group ( $p>0.05)$

(Table 2).

\section{Intra-group Evaluation}

In the PJI group, there was a significant difference between the results of the first and second samples in all parameters $(p<0.01)$. Platelet count, ESR, and CRP were significantly higher in the second sample, and MPV was significantly lower. No significant difference was observed in the intra- group evaluations of the TKA and control groups ( $p>0.05)$ (Table 2).

\section{MPV Cut-off Value in the PJI Group}

MPV values of the PJI group were significantly lower compared to the control group and TKA group. Based on this significance, $\mathrm{ROC}$ analysis and diagnostic screening tests were used to determine that cut-off value for MPV was 7,2 and below in the PJI group (Table 3). 
Table 4. Platelet Count cut-off value and ROC Curve Results in the PJI group

\begin{tabular}{|c|c|c|c|c|c|c|c|c|}
\hline & \multicolumn{5}{|c|}{ Diagnostic Scan } & \multicolumn{2}{|c|}{ ROC Curve } & \multirow[t]{2}{*}{$p$} \\
\hline & Cut off & Sensitivite & Spesifisite & $\begin{array}{l}\text { Positive } \\
\text { Predictive } \\
\text { Value }\end{array}$ & $\begin{array}{c}\text { Negative } \\
\text { Predictive } \\
\text { Value }\end{array}$ & Area & $\begin{array}{c}95 \% \\
\text { Confidence } \\
\text { Interval }\end{array}$ & \\
\hline PLT & $\geq 412$ & 54.05 & 77.14 & 71.43 & 61.36 & 0.688 & $0.566-0.810$ & $0.006 *$ \\
\hline
\end{tabular}

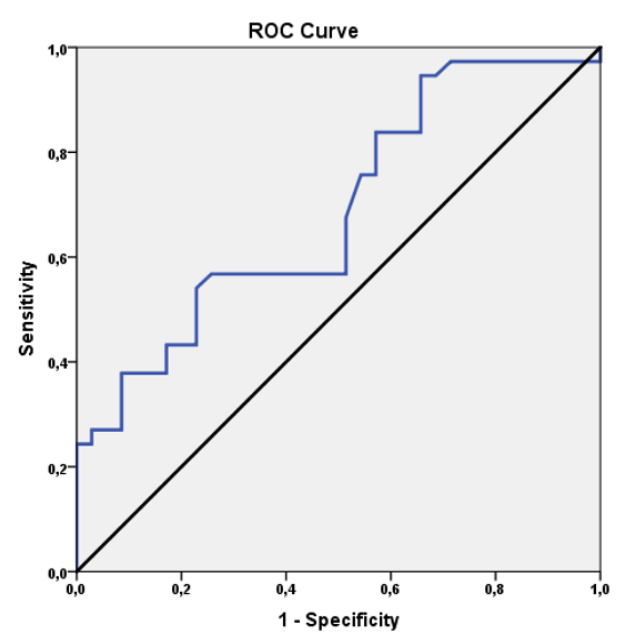

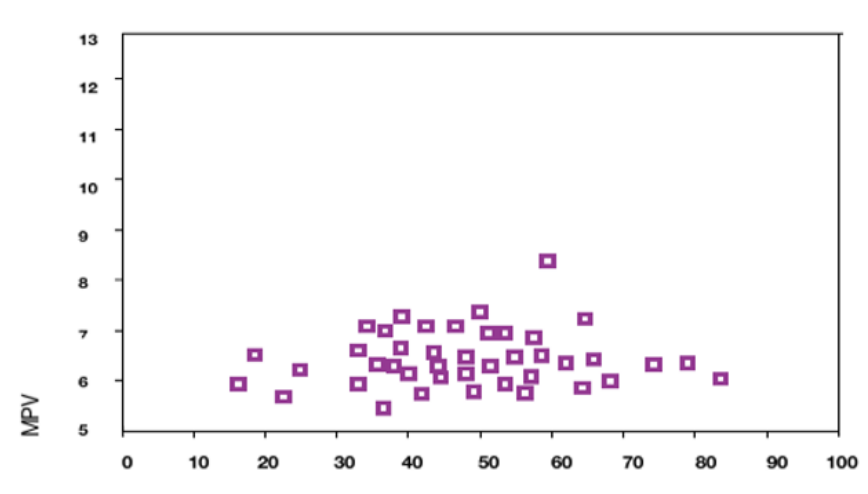

ESR

Figure 1. MPV and ESR correlation in the periprosthetic joint infection group

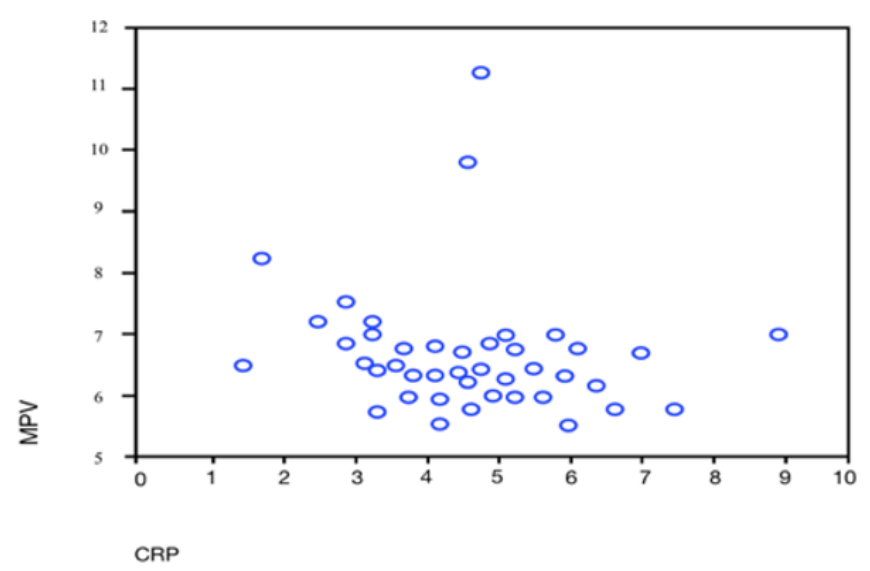

Figure 2. MPV and CRP correlation in the periprosthetic joint infection group

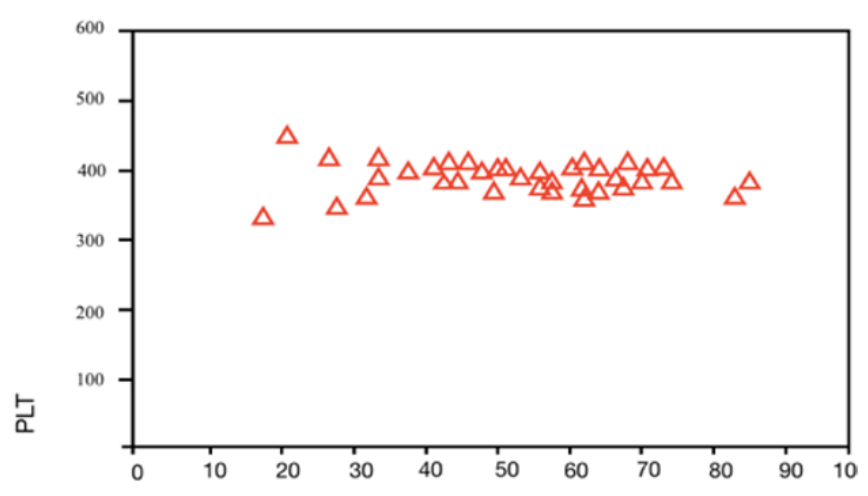

ESR

Figure 3. PLT and CRP correlation in the periprosthetic joint infection group

\section{Platelet Cut-off Value in the PJI Group}

Platelet count of the PJI group was significantly higher compared to the control group and TKA group. Based on this significance, $\mathrm{ROC}$ analysis and diagnostic screening tests were used to determine that cut-off value for platelet count was 412 and upper in the PJI group (Table 4).

\section{Correlation Evaluation}

MPV and platelet count were strongly correlated with both ESR and CRP in the PJI group. According to Pearson's correlation test, MPV negatively correlated with ESR and CRP (Figure 1, Figure 2) and positively correlated with platelet count (Figure 3, Figure 4). 


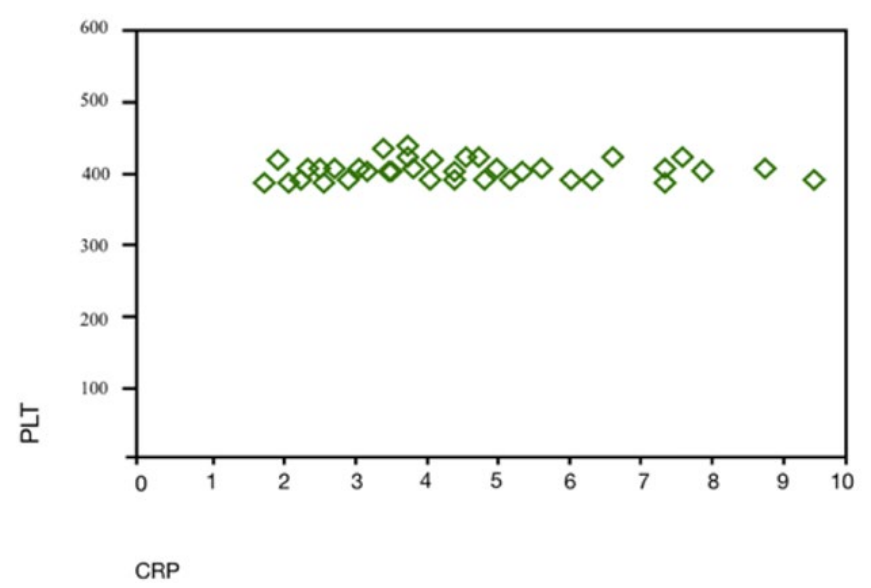

Figure 4. PLT and CRP correlation in the periprosthetic joint infection group

\section{DISCUSSION}

Different society groups have previously attempted to standardize the definition of periprosthetic joint infection $[9,10]$. Although definite evidence or major criteria for infection are similar between the various definitions, the supportive evidence or minor criteria differ and are less agreed upon [11-13]. In recent years, novel laboratory tests are used to diagnose periprosthetic infections. Some of these include serum D-dimer, synovial leukocyte esterase (LE), synovial alpha defensin, and synovial CRP $[14,15]$. Publications have shown different weights (sensitivity and specificity) for the various tests used and highlight the value of a high pretest probability in the overall diagnosis [16]. The most recent studies have demonstrated that MPV and platelet count have started to be used as independent markers in diagnosis of infection $[17,18]$. In our study, we found that MPV and platelet count also fluctuate like other known laboratory values, in PJI patients. We found that MPV was lower than normal and platelet count was higher than normal in PJI patients.

Robbins et al. reported that excessive production of proinflammatory cytokines and acute phase reactants affected megakaryopoiesis and suppressed platelet sizes, resulting in smaller platelets released from the bone marrow, as well as inducing thrombopoesis, resulting in thrombocytosis and decreased MPV levels in infections and acute inflammatory events [17].

Zareifar et al. observed decreased MPV and increased platelet count in the active period of patients diagnosed with infection or inflammation and also reported correlation with ESR and CRP [18].

In our study, it was observed that the patients in the PJI group had significantly lower MPV and significantly higher platelet count during their diagnosis period. MPV was also correlated with platelet count, CRP, and ESR.

Kapsoritakis et al. reported that MPV acted similar to negative acute phase reactants in inflammatory diseases, and that it was correlated with CRP and ESR. They concluded that MPV may be used as an independent marker like other indicators [19].

In our study, we also found that MPV and platelet count were in normal ranges in the control group and TKA group, and that correlations with ESR and CRP were statistically significant. Therefore, we identified that MPV and platelet count may be used in laboratory evaluation for diagnosing infection.

Van der Lelie et al. indicated that MPV and platelet count were high in patients with septicemia [20]. However, the blood samples of patients in that study were collected on the first day of septicemia. On the other hand, the literature indicates that decrease in MPV and increase in platelet count occurs after the tenth day [17]. In our study, it was unknown exactly when the periprostatic knee infections of the patients had started. Therefore, the patients of the PJI group with normal or elevated MPV values may have been due to blood samples collected during this time period.

Rodriguez et al. conducted a meta-analysis and reported the prevalence of various microorganisms encountered in patients with periprosthetic joint infection. The most frequently isolated microorganism was coagulase-negative Staphylococcus aureus [21]. In our study, we determined that the types of bacteria observed in the cultures of the patients and their prevalence rates were consistent with the literature.

\section{Limitations}

Limitations of our study were that the number of patients were low, the control group consisted of young subjects, and the possibility of low-virulence disease that cannot be detected during examinations or other pathologies which are not yet in the literature but are likely to affect MPV. In addition, follow-up blood samples of patients with knee prosthesis who did not have PJl were collected in the sixth month, which may have caused inflammatory mediators produced in the postoperative period to have affected MPV. Studies have shown that it may take up to three months after operation for inflammatory mediators to return to normal levels $[6,7]$. 


\section{CONCLUSION}

The results of our study indicate that MPV may be a useful laboratory parameter in the diagnosis of periprosthetic knee infection following knee prosthesis surgery. The likelihood of infection is especially high in patients with MPV of 7.2 or less. However, we must not forget that medicine is a branch of science based on evidence. The more data to support diagnosis, the greater the belief in treatment. Further prospective studies will shed more light on this subject.

\section{ETHICS APPROVAL AND CONSENT TO PARTICIPATE}

This retrospective study was approved and consented to participate by the Ethics Committee of Fatih Sultan Mehmet Training and Research Hospital.

\section{DECLARATION OF CONFLICT OF INTEREST}

The authors received no financial support for the research and/or authorship of this article. There is no conflict of interest.

\section{REFERENCES}

1. Widmer AF. New developments in diagnosis and treatment of infection in orthopedic implants. Clinical Infectious Diseases, 33(Supplement_2): 94-106. (doi: 10.1086/321863).

2. Parvizi J, Adeli B, Zmistowski B, Restrepo C, Greenwald AS. Management of periprosthetic joint infection: the current knowledge: AAOS exhibit selection. J Bone Joint Surg Am 2012; 94(14): e104. (doi: 10.2106/JBJS.K.01417).

3. Kurtz SM, Ong KL, Lau E, Bozic KJ, Berry D, Parvizi J. Prosthetic joint infection risk after TKA in the Medicare population. Clinical Orthopaedics and Related Research, 2010; 468(1): 52-6. (doi: 10.1007/s1 1999-009-1013-5).

4. Morgenstern C, Cabric S, Perka C, Trampuz A, Renz N. Synovial fluid multiplex PCR is superior to culture for detection of low-virulent pathogens causing periprosthetic joint infection. Diagnostic microbiology and infectious disease, 2018; 90(2): 115-9. (doi: 10.1016/j.diagmicrobio.2017.10.016).

5. Fernandez-Sampedro M, Farin-as-Alvarez C, GarcesZarzalejo C, Alonso- Aguirre MA, Salas-Venero C, Martínez-Martínez $L$, et al. Accuracy of different diagnostic tests for early, delayed and late prosthetic joint infection. BMC Infect Dis 2017; 17: 592. (doi: 10.1186/s12879-017-2693-1).
6. Martin JF, et al. Measurement of the density of human platelets and its relationship to volume. British journal of haematology 1983; 54(3): 337-52. (doi: 10.1111/j.13652141.1983.00337.x).

7. Yuri Gasparyan A, Ayvazyan L, P Mikhailidis D, D Kitas G. Mean platelet volume: a link between thrombosis and inflammation?. Current pharmaceutical design, 2011; 17(1): 47-58. (doi: 10.2174/138161211795049804).

8. Hameed MA, Waqas S. Physiological basis and clinical utility of erythrocyte sedimentation rate. Pak J Med Sci 2006; 22(2): 214-8.

9. Osmon DR, Berbari EF, Berendt AR, Lew D, Zimmerli W, Steckelberg JM, et al. Executive summary: diagnosis and management of prosthetic joint infection: clinical practice guidelines by the Infectious Diseases Society of America. Clin Infect Dis Off Publ Infect Dis Soc Am 2013; 56: 1e10. (doi: 10.1093/ cid/cis966).

10. Parvizi J, Zmistowski B, Berbari EF, Bauer TW, Springer BD, Della Valle $C J$, et al. New definition for periprosthetic joint infection: from the Workgroup of the musculoskeletal infection society. Clin Orthop 2011; 469: 2992e4. (doi: 10.1007/s11999-011-2102-9).

11. Patel $R$, Alijanipour $P$, Parvizi J. Advancements in diagnosing periprosthetic joint infections after total hip and knee arthroplasty. Open Orthop J 2016; 10: 654e61. (doi: 10.2174/1874325001610010654).

12. Deirmengian C, Kardos K, Kilmartin P, Cameron A, Schiller K, Parvizi J. Diag- nosing periprosthetic joint infection: has the era of the biomarker arrived? Clin Orthop 2014; 472: 3254e62. (doi: 10.1007/s11999-014-3543-8).

13. Lee YS, Koo K-H, Kim HJ, Tian S, Kim TY, Maltenfort MG, et al. Synovial fluid biomarkers for the diagnosis of periprosthetic joint infection: a systematic review and meta-analysis. J Bone Joint Surg Am 2017; 99: 2077 e84. (doi: 10.2106/JBJS.17.00123).

14. Kitazawa, T, et al. Changes in the mean platelet volume levels after bloodstream infection have prognostic value. Internal Medicine 2013; 52(13): 1487-93. (doi: 10.2169/internalmedicine.52.9555).

15. Bottner F, Wegner A, Winkelmann W, Becker K, Erren M, Götze C. Interleukin-6, procalcitonin and TNF-a: markers of peri-prosthetic infection following total joint replacement. The Journal of bone and joint surgery. British volume, 2007; 89(1): 94-9. (doi: 10.1302/0301620X.89B1.17485). 
16. Parvizi J, Tan TL, Goswami K, Higuera C, Della Valle C, Chen AF, Shohat N. The 2018 definition of periprosthetic hip and knee infection: an evidence-based and validated criterion. The Journal of arthroplasty, 2018; 33(5): 130914. (doi: 10.1016/j.arth.2018.02.078).

17. Robbins G, Barnard DL. Mean platelet volume changes in infection. Journal of clinical pathology 1983; 36(11): 1320. (doi: 10.1136/jcp.36.11.1320-a).

18. Zareifar S, Farahmand Far MR, Golfeshan F, Cohan N. Changes in platelet count and mean platelet volume during infectious and inflammatory disease and their correlation with ESR and CRP. Journal of clinical laboratory analysis, 2014; 28(3): 245-8. (doi: 10.1002/jcla.21673).
19. Kapsoritakis AN, Koukourakis MI, Sfiridaki A, Potamianos SP, Kosmadaki MG, Koutroubakis IE, Kouroumalis EA. Mean platelet volume: a useful marker of inflammatory bowel disease activity. The American journal of gastroenterology, 2001; 96(3): 776-81. (doi: 10.1016/S0002-9270(00)02414-X).

20. Van der Lelie J, Von dem Borne AK. Increased mean platelet volume in septicaemia. Journal of clinical pathology 1983; 36(6): 693-6. (doi: 10.1136/jcp.36.6.693).

21. Rodríguez-Merchán EC, Liddle AD. Microbiological concepts of the infected total knee arthroplasty. In The Infected Total Knee Arthroplasty (pp. 11-17). Springer, Cham. 2018. (doi: 10.1007/978-3-319-66730-0). 